\title{
Maximize The Yield and Water Productivity by Investigating The Most Appropriate Rice Transplanting Methods under Saline and Non Saline Soils in North Delta of Egypt
}

\author{
Abou Khadrah, S. H; ${ }^{1}$ Shimaa A. Badawy ${ }^{1}$; Saeid,M.M. ${ }^{2}$; Asmaa .M. El-Shahawy ${ }^{2}$
}

\begin{abstract}
A field experiments was conducted at Sakha Agricultural Research Station, Kafr El-Sheikh Governorate in two soils (saline and non saline) during 2009 / 2010 rice growing season. The present study was designed to determine the most appropriate rice (Oryza sativa L.) transplanting methods to maximize the productivity of rice grain yield, net profit and water productivity of rice crop in North Delta, Egypt.
\end{abstract}

The experimental design was a randomized complete block with four replications. Eight treatments were established in the permanent field, as follows:

T1 (random transplanting),

T2 (regular transplanting $20 \times 20 \mathrm{~cm}$ ),

T3 (transplanting on beds $80 \mathrm{~cm}$ wide), seedlings were transplanting in hills (4-5 plants) on two sides,

T4 (transplanting on beds $80 \mathrm{~cm}$ wide), seedlings were transplanted in hills (4-5 plants) on bottom,

T5 (transplanting on beds $80 \mathrm{~cm}$ wide), seedlings were transplanted in hills (4-5 plants) on top and bottom,

T6 (transplanting of furrows $60 \mathrm{~cm}$ wide), seedlings were transplanted in hills (4-5 plants) on two sides,

T7 (transplanting of furrow $60 \mathrm{~cm}$ wide), seedlings were transplanted in hills (4-5 plants) on bottom.

T8 (transplanting of furrows $60 \mathrm{~cm}$ wide), seedlings were transplanted in hills (4-5 plants) on top and bottom.

The following results could be summarized as follows:

Data showed that the traditional method of transplanting received the highest amount of irrigation water. While, the transplanting on beds and furrow used less amount of irrigation water compared to traditional method of transplanting and regular transplanting method.

Data revealed that the irrigation water can be saved by 0.336, 1.204, 1.277, 1.108, 1.025, 1.066 and $0.932 \mathrm{~m}^{3} / \mathrm{fed}$. With T2, T3, T4, T5, T6, T7 and T8 compared to conventional transplanting method. This quantity of water saving could be enough to cultivate rice area; 51.43, 185.6, 196.84, 170.66, 158.07, 164.36 and 143.68 thousands feddans under Kafr El-Sheikh governorate condition.

Data indicated that the highest values of field water use efficiency was obtained from T3 (transplanting on beds 80 cm wide), seedlings were transplanted in hills (4-5 plants) on two sides in normal and saline soils. While, the lowest value was resulted from $\mathrm{T} 1$ (traditional method of transplanting) under normal and saline soils conditions. Data showed that the maximum rice grain and straw yield were produced by the treatment of $\mathrm{T} 2$ compared to $\mathrm{T} 1$ in both seasons. The lowest grain and straw yield were recorded with $\mathrm{T} 7$ and $\mathrm{T8}$ transplanting method. The highest mean values of 1000-grain weight were obtained by T7 treatment in normal and saline soils, respectively. While, the lowest values were resulted from $\mathrm{T} 1$ in normal soil and T4 in saline soil.

Data indicated that the highest values of total income, net profit, water productivity and economic efficiency were realized when using regular transplanting of rice at North Delta. While, the lowest values were recorded with transplanting rice on beds and bottom of furrows with 60 cm wide.

\section{INTRODUCTION}

Rice is one of the most important crops in Egypt providing a high source of income. It is a main stable food for the majority of the population and has become a cash crop. All the rice cultivated in Egypt is low-land rice. So, despite of the free cropping pattern policy which has been adopted in the 1980, rice remains an exception such that the areas entitled to cultivate rice are defined by the Ministry of Water Resources and Irrigation (MWRI) to about 1.1 million fed. /year. Regarding the Egyptian conditions, rice is one of the major water consuming crops and continuous flooding is the only method used for irrigation by the farmers. The limitation of water resources and the remarkable increase in population should be forced research workers to find ways for saving some of this water without significant reduction in yield. Thus, saving the water is becoming decisive factor for agricultural expansion. Great efforts should be done through improving the agronomic practices, such as planting methods and water management to finding ways for saving more irrigation water.

Egypt is becoming more and more a water poor country. The per capita share of water is now 780 $\mathrm{m}^{3} /$ person/year, which is below the so-called poverty line and expected to go further down with time. Irrigation is generally defined as the application of water to soil for the purpose of supplying the moisture essential for plant

\footnotetext{
${ }^{1}$ Department of Agronomy, faculty of agriculture,

Kafrelsheikh University.

${ }^{2}$ Field Crop Research Institute, A.R.C, Egypt

Received November 9, 2013, Accepted December 25, 2013
} 
growth. However, efficient use of irrigation water is an obligation of each user. However, efficiency of water use will vary from method to another. In areas where water is scarce and costly, available water should be used carefully.

Water is considered the major constraint for any policy to increase agriculture productivity. Since the present water supply is limited, water demand is augmenting to face the incessant increase in population. Thus, it was necessary to control and manage the available water supply to face overuse problem and minimize water losses from water courses to improve irrigation efficiency. Sufficient water should be applied to the plant to obtain the highest possible yields with less losses of water over irrigation pushes water beyond the root zone or be accumulated at tail end of the field causing excessive run off and plant health degradation.

To mitigate the increasing water scarcity in Egypt, new ways of growing rice need to be developed that use less water than conventional low land rice.

The present study is designed to determine the most appropriate planting method of rice which can maximize yield and net profit in North Delta, Egypt. It may be interested to evaluate these planting methods together through their impacts on water use efficiency and rice crop production. So, the objectives of this research are to study the effect of different planting methods on irrigation efficiencies, calculating the amount of water saving and effect of different planting methods on the yield of rice crop as well as water use efficiency.

\section{MATERIALIS AND METHODS}

One field experiment was conducted during 2009/2010 rice seasons in two soils (saline and non saline) at Sakha Agriculture Research station, Kafr ElSheikh Governorate. The present study was designed to determine the most appropriate planting method and water productivity of rice to maximize the rice grain yield in North Delta, Egypt.

The experimental design was randomized complete block with four replicates. The experiment consists of 32 plots and each plot was $10.5 \mathrm{~m}^{2}(3 \times 3.5 \mathrm{~m})$. Eight treatments were established in the permanent field, as follows:

$\mathrm{T} 1=$ (random transplanting) random transplanting of rice seedlings on flat soil.

$\mathrm{T} 2=$ Regular transplanting on flat soil $20 \times 20 \mathrm{~cm}$.

$\mathrm{T} 3=$ Transplanting on beds $80 \mathrm{~cm}$ wide, seedlings were transplanted in hills (4-5 plants) on two sides.

T4= Transplanting on beds $80 \mathrm{~cm}$, wide, seedlings were transplanted in hills (4-5 plants) on bottom.
T5= Transplanting on beds $80 \mathrm{~cm}$ wide, seedlings were transplanted in hills (4-5 plants) on top and bottom.

T6= Transplanting of furrows $60 \mathrm{~cm}$ wide, seedlings were transplanted in hills (4-5 plants) on two sides.

$\mathrm{T} 7=$ Transplanting of furrows $60 \mathrm{~cm}$ wide, seedlings were transplanted in hills (4-5 plants) on bottom.

$\mathrm{T} 8=$ Transplanting of furrow $60 \mathrm{~cm}$ wide, seedling were transplanted in hills (4-5 plants) on top and bottom.

The plant density on all above mentioned planting methods has been adjusted to be 25 hills $/ \mathrm{m}^{2}$.

The amount of irrigation water delivered to the plots of the different treatments was measured and recorded using the cut-throat flumes $(30-90 \mathrm{~cm})$. The amount of water used was calculated for both land preparation and nurseries (30 days seedling age) and permanent field. Plots were continuously flooded to a depth of $7 \mathrm{~cm}$ as a static head above soil surface every six days for the traditional planting and $7 \mathrm{~cm}$ from the bottom to the top of furrows and beds. The amount of irrigation water delivered to each treatment was also recorded and added to get the total used. Irrigation of the permanent field started after six days from transplanting process and stopped at 25 days after complete heading (one week before harvesting) in both seasons. Field water use efficiency (FWUE) was calculated according to Michael (1978).

FWUE $\left(\mathrm{kg} / \mathrm{m}^{3}\right)=\frac{\text { Rice grain yield }(\mathrm{kg} / \mathrm{fed} .)}{\text { Total amount of water applied }\left(\mathrm{m}^{3} / \mathrm{fed} .\right)}$

Rice cultivars Sakha 104 was sown in the nursery on June $1^{\text {st }}$ and $5^{\text {th }}$ in 2009 and 2010, respectively. Thirty days old seedlings were transplanted in hills at spacing 20 by $20 \mathrm{~cm}$ to give $25 \mathrm{hills} / \mathrm{m}^{2}$ for random transplanting and spaced $(13$ by $13 \mathrm{~cm}$ ) in the two rows in bottom of furrows to keep population on 25 hills $/ \mathrm{m} 2$ for furrows, and spaced $(10$ by $10 \mathrm{~cm})$ in the two rows in bottom of bed to keep population on 25 hills $/ \mathrm{m} 2$ for beds. Cultural practices were similar to those used in the area. Rice plants were harvested at 135 days from sowing. Rice yield was determined by crop-cut sampling in two diagonally opposite corners of each plot using a $1 \mathrm{~m} \mathrm{x} 1$ $\mathrm{m}$ sampling frame in the experiment. Ten plants were chosen at random from this frame to determine: Plant height $(\mathrm{cm})$, Spike length $(\mathrm{cm})$, No. of tillers/plant, No. of grains/spike, Rice grain and straw yield (ton/fed.), Spike weight (gm),1000 grain weight (gm)

Soil samples were compared before planting from different soil layers, air dried, ground, sieved and stored for physical and chemical analysis were presented in Table (1). Particle size distribution for soil was carried out using the pipette method, as described by (Dewis and Farias, 1970). 
Table1. Chemical properties of the soil samples taken from Sakha Agricultural Research station, in the normal and saline soils

\begin{tabular}{|c|c|c|c|c|c|c|c|c|c|c|c|}
\hline \multirow{2}{*}{ Depth (cm) } & \multirow{2}{*}{$\begin{array}{c}\text { EC } \\
\text { ds } / m\end{array}$} & \multirow{2}{*}{ PH } & \multirow{2}{*}{ SAR } & \multicolumn{4}{|c|}{ Soluble cations (meq/L) } & \multicolumn{4}{|c|}{ Soluble anions (meg/L) } \\
\hline & & & & $\mathrm{Na}^{+}$ & $\mathbf{K}^{+}$ & $\mathrm{Ca}^{++}$ & $\mathbf{M g}^{++}$ & $\mathrm{CO}_{3}{ }^{=}$ & $\mathrm{HCO}_{3}^{-}$ & $\mathrm{Cl}^{-}$ & $\mathrm{SO}_{4}{ }^{=}$ \\
\hline \multicolumn{12}{|c|}{ Normal soil } \\
\hline $0-30$ & 3.82 & 7.96 & 10.79 & 27.10 & 0.6 & 7.60 & 5.00 & 0.0 & 4.50 & 19.0 & 11.4 \\
\hline $30-60$ & 3.62 & 8.05 & 10.54 & 25.70 & 0.5 & 7.20 & 4.70 & 0.0 & 4.00 & 18.0 & 11.1 \\
\hline \multicolumn{12}{|c|}{ Saline soil } \\
\hline $0-30$ & 7.50 & 8.1 & 13.51 & 51.0 & 0.8 & 12.0 & 16.5 & 0.0 & 9 & 35.7 & 35.6 \\
\hline $30-60$ & 7.65 & 8.09 & 13.64 & 52.0 & 0.8 & 12.2 & 16.8 & 0.0 & 9.5 & 36.4 & 35.9 \\
\hline
\end{tabular}

All the obtained data were statistically analyzed using analysis of variance technique and significant means were separated using least significant difference test (LSD) for comparing the treatment means Snedecor and Cochran (1980).

Bulk density was determined using cylindrical sharp edged as described by Vomocil (1957). Soil chemical analysis was determined according to Jackson (1967). Sodium adsorption ration (SAR) was calculated in soil paste extract as follows:

$$
S A R=\frac{N a}{\sqrt{\left(\mathrm{Ca}^{++}+M g^{++}\right) / 2}}
$$

Where: $\quad \mathrm{SAR}=$ Sodium adsorption ratio. Field capacity (FC) and permanent wilting point (PWP) were determined by using pressure membrane at $1 / 3$ and 15 bar, respectively (Black, 1965).Available water (AW) was calculated as a difference between field capacity and wilting point values (James, 1988).

\section{RESULTS AND DISCUSSION}

Effect of different planting methods on some water relations:

The amount of irrigation water applied is presented in Table (2). The total amount of applied water for each season during rice growth stages was varied according to the differences between planting methods. All tests of transplanting on beds and furrows methods used less amount of water compared to traditional transplanting and regular transplanting methods.

Average volumes of applied water for traditional transplanting were 6485 and $6675 \mathrm{~m}^{3} /$ fed for seasons 2009 and 2010, respectively. The average volumes of applied water for regular transplanting method on flat soil were $5831,5978 \mathrm{~m}^{3} / \mathrm{fed}$. for normal and saline soils, respectively.

Data obtained showed that, the total amount of water applied were $4125,3982,4315,4475,4395$ and 4658 $\mathrm{m}^{3} /$ fed., and 4245, 4193, 4445, 4567, 4643 and 4813 $\mathrm{m}^{3}$ /fed. For T3, T4, T5, T6, T7 and T8 treatments over both normal and saline soils, respectively.

It was evident that $\mathrm{T} 1$ (traditional transplanting) transplanting of rice seedlings on flat soil received the highest amount of irrigation water for normal and saline soils, respectively. While T4 (transplanting on beds 80 cm wide, which seedlings were transplanted in hills (4-5 plants) on bottom received the lowest amount of irrigation water for normal and saline soils, respectively. This difference between the tested planting methods could be attributed to shortening the time of applying irrigation water where the water was added by the required depth only beneath the furrows or beds in case of T4 treatment while in case of T1 treatment the whole field is inundated with irrigation water which most of it may be lost due to seepage and deep percolation.

The irrigation water applied was 9028.6, 10047.6 and $15628.6 \mathrm{~m}^{3} /$ ha for planting in strips of furrows 80 $\mathrm{cm}$ wide, planting in strips of furrows $60 \mathrm{~cm}$ wide and traditional planting (Atta et al., 2006), respectively.Meleha et al. (2008) showed that the means of irrigation water applied were $1480 \mathrm{~mm}, 1013 \mathrm{~mm}$, and $919 \mathrm{~mm}$ for traditional planting, planting in bottom of furrows and beds, respectively. Methods of planting in bottom of furrows and beds saved $31.06 \%$ and $37.9 \%$ of irrigation water compared to traditional planting method, respectively.

Saving Water:

Table (2) indicated that the amount of water saving compared to $\mathrm{T} 1$ in the treatments of T2, T3, T4, T5, T6, T7 and T8 were 654 (10.08\%), 2360 (36.39\%), 2503 (38.59\%), 2170 (33.46\%),2010 (31.0\%), 2090 (32.23\%) and $1827(28.17 \%) \mathrm{m}^{3} /$ fed. in the normal soil and 697 (10.44\%), 2430 (36.40\%), 2482 (37.18\%), 2230 (33.41\%), 2108 (31.58\%), $2212 \quad(33.14 \%)$ and $1862(27.89 \%) \mathrm{m}^{3} /$ fed. in the saline soil, respectively, as compared to traditional method.

Such results indicate that the planting of rice in beds (T4) and furrows (T7) saved 38.59\%, 37.18\% and $32.23 \%$, $33.14 \%$ of irrigation water compared to traditional planting method over the two seasons, respectively. The results are in accordance with those reported by Atta et al. (2006), Jagroop et al. (2007), and Meleha et al. (2008). 
Table 2.Amount of water saving ( $\mathrm{m}^{3} / \mathrm{fed}$.) due to different planting methods for rice crop in normal soil and saline soil

\begin{tabular}{|c|c|c|c|c|}
\hline \multicolumn{2}{|c|}{ Treatments } & \multirow{3}{*}{$\begin{array}{c}\text { Total water applied }\left(\mathbf{m}^{\mathbf{3}} / \mathbf{f e d}\right) \\
5831\end{array}$} & \multicolumn{2}{|c|}{ Water saving } \\
\hline & & & \multirow{2}{*}{$\begin{array}{c}\mathbf{m}^{3} / \mathbf{f e d} \\
654 \\
\end{array}$} & \multirow{2}{*}{$\begin{array}{c}\% \\
10.08 \\
\end{array}$} \\
\hline Normal soil & $\mathrm{T} 2$ & & & \\
\hline & T3 & 4125 & 2360 & 36.39 \\
\hline & $\mathrm{T} 4$ & 3982 & 2503 & 38.59 \\
\hline & T5 & 4315 & 2170 & 33.46 \\
\hline & T6 & 4475 & 2010 & 31.00 \\
\hline & $\mathrm{T} 7$ & 4395 & 2090 & 32.23 \\
\hline & $\mathrm{T} 8$ & 4658 & 1827 & 28.17 \\
\hline \multirow[t]{7}{*}{ Saline soil } & $\mathrm{T} 2$ & 5978 & 697 & 10.44 \\
\hline & T3 & 4245 & 2430 & 36.40 \\
\hline & $\mathrm{T} 4$ & 4193 & 2482 & 37.18 \\
\hline & T5 & 4445 & 2230 & 33.41 \\
\hline & T6 & 4567 & 2108 & 31.58 \\
\hline & $\mathrm{T} 7$ & 4463 & 2212 & 33.14 \\
\hline & T8 & 5978 & 697 & 10.44 \\
\hline
\end{tabular}

In general, it can be concluded that water is becoming an economically scarce resource in many areas in the world. So, the use of transplanting of beds (T4, T3 and T5) or furrows (T7) becomes very important to save and optimize use of water, estimating economic of irrigation water becomes very important for planning irrigation management.

Table (2) showed that the irrigation water can be saved by $0.336,1.204,1.277,1.108,1.025,1.066$ and $0.932 \mathrm{~m}^{3} /$ fed., with T2, T3, T4, T5, T6, T7 and T8 compared to conventional transplanting method which represents the farmers practices in the studied area under Kafr El-Sheikh conditions in the normal soil.

In the Saline soil, the irrigation water can be saved by $0.418,1.458,1.489,1.338,1.242,1.327$ and 1.117 $\mathrm{m}^{3} /$ fed with T2, T3, T4, T5, T6, T7 and T8 treatments methods compared to conventional transplanting method which represents the farmer practices in the studied area under Kafr El-Sheikh conditions.

Therefore, it can be concluded that the area cultivated by rice may be increased in the future if the farmers apply these techniques of planting methods.

\section{Field water use efficiency (FWUE):}

Table (3) showed that the highest value of field water use efficiency $(0.697 \mathrm{~kg} / \mathrm{m} 3)$ was obtained from T3 (transplanting on beds $80 \mathrm{~cm}$, wide) and seedlings were transplanted in hills (4-5 plants) on two sides. While, the lowest value of field water use efficiency $(0.395 \mathrm{~kg} / \mathrm{m} 3)$ was resulted from the T8 (transplanting of furrows $60 \mathrm{~cm}$ wide, seedling were transplanted in hills (4-5 plants) on top and bottom under normal soil conditions. While, under saline soil conditions, the highest value of $(0.664 \mathrm{~kg} / \mathrm{fed}$.) was obtained by the treatment of T3 and the lowest value $\left(0.420 \mathrm{~kg} / \mathrm{m}^{3}\right)$ is resulted from $\mathrm{T} 1$ (traditional transplanting) of rice seedlings on flat soil.

It could be noticed that field water use efficiency values were higher for treatments having higher rice yield (grain and straw) and less water applied. Depending on the intended purpose and the domain of interest, many efficiency concepts are involved such as crop water-use efficiency, water application efficiency, and others (Israelsen, 1962; Jensen, 1980). Such finding could be ascribed to the marked reduction in the amount of water used with a significant increase in grain yield. Similar results were obtained by Atta (2005), Atta et al. (2006) and Meleha et al. (2008).

Effect of transplanting methods on yield and yield components of rice under normal soil condition:

Table (4) showed that the maximum rice grain yield (3.445 ton/fed) was produced by the treatment $\mathrm{T} 2$. Results indicated that the maximum values of relative change $\pm \%$ was increased by $3.13 \%$ with the treatment of T2 as compared with traditional transplanting method (T1) on the other hand grain yield decreased by the rest treatments as compared with traditional transplanting method (T1) under normal soil condition. These results are in agreement with those obtained by Ockerby and Fukaib (2001) who pointed out that the rice grain yield ranged from 710 to $1250 \mathrm{~g} / \mathrm{m}^{2}$ and was slightly greater in paddy than raised beds.

Data in Table (4) showed that the maximum paddy straw yield (3.963 ton /fed) was produced by the treatment of $\mathrm{T} 2$. The relative increase was about 
( $8.52 \%)$ by $\mathrm{T} 2$ treatment, but it was decreased by the other transplanting methods, as compared with the normal transplanting. The lowest straw yield is obtained by $\mathrm{T} 7$ and $\mathrm{T} 8$ transplanting methods since it produced grain and straw yield lower than that produced by $\mathrm{T} 2$ transplanting method.

Data in Table (5) indicated that the 1000 grain weights of the rice have been highly significantly affected by transplanting methods. The highest mean value was 5.77 by $\mathrm{T} 7$ treatment and the lowest value $5.14 \mathrm{~g}$ was recorded by $\mathrm{T} 1$ treatment, under normal soil condition.

Table (5) results pointed out that the panicle weight (g) of the rice had been highly significantly affected by transplanting methods. The highest mean obtained value was $3.98 \mathrm{~g}$ by $\mathrm{T} 6$ while, the lowest value was recorded by transplanting methods (T7), respectively. Results show highly significant differences existed due to transplanting methods. Where transplanting method (T4) gave the highest number of grains/panicle (133.5), as compared with transplanting methods (T8) which recorded (111) grains/panicle, respectively. Table (6) revealed that the No. of tillers/plant of the rice, have been highly significantly affected by transplanting methods. The highest mean value (15.8) were achieved by transplanting method (T6) while the lowest value was recorded by transplanting method of (T8) as compared with traditional irrigation transplanting.

Table 3. Field water use efficiency $\left(\mathrm{kg} / \mathrm{m}^{3}\right)$ as affected by different planting methods under normal and saline soil conditions

\begin{tabular}{|c|c|c|c|c|c|}
\hline \multirow[b]{2}{*}{ Treatment } & \multirow[b]{2}{*}{$\begin{array}{c}\text { Rice grain yield } \\
\text { (ton/fed) }\end{array}$} & \multirow[b]{2}{*}{$\begin{array}{c}\text { Rice straw yield } \\
\text { (ton/fed) }\end{array}$} & \multirow{2}{*}{$\begin{array}{c}\text { Total water } \\
\text { applied } \\
\left(\mathbf{m}^{3} / \text { fed }\right) \\
\end{array}$} & \multicolumn{2}{|c|}{ Field water use efficiency $\left(\mathrm{kg} / \mathrm{m}^{3}\right)$} \\
\hline & & & & Grain $\left(\mathrm{kg} / \mathrm{m}^{3}\right)$ & Straw $\left(\mathrm{kg} / \mathrm{m}^{3}\right)$ \\
\hline \multicolumn{6}{|c|}{ Normal soil } \\
\hline T1 & $3.337 \mathrm{a}$ & $3.652 \mathrm{~b}$ & 6485 & 0.515 & 0.563 \\
\hline $\mathrm{T} 2$ & $3.445 \mathrm{a}$ & $3.963 \mathrm{a}$ & 5831 & 0.590 & 0.679 \\
\hline T3 & $2.875 \mathrm{~b}$ & $3.411 \mathrm{c}$ & 4125 & 0.697 & 0.827 \\
\hline T4 & $2.583 \mathrm{c}$ & $2.913 \mathrm{~d}$ & 3982 & 0.649 & 0.731 \\
\hline T5 & $2.347 \mathrm{~d}$ & $2.699 \mathrm{e}$ & 4315 & 0.544 & 0.626 \\
\hline T6 & $2.572 \mathrm{c}$ & $2.948 \mathrm{~d}$ & 4475 & 0.575 & 0.659 \\
\hline T7 & $1.969 \mathrm{e}$ & $2.221 \mathrm{f}$ & 4395 & 0.448 & 0.505 \\
\hline T8 & $1.843 \mathrm{f}$ & $2.141 \mathrm{~g}$ & 4658 & 0.395 & 0.459 \\
\hline \multicolumn{6}{|c|}{ Saline soil } \\
\hline T1 & $2.805 \mathrm{bc}$ & $4.212 \mathrm{a}$ & 6675 & 0.420 & 0.547 \\
\hline T2 & $3.23 \mathrm{a}$ & $4.132 \mathrm{a}$ & 5978 & 0.540 & 0.663 \\
\hline T3 & $2.821 \mathrm{~b}$ & $3.213 \mathrm{~b}$ & 4245 & 0.664 & 0.804 \\
\hline T4 & $2.570 \mathrm{bcd}$ & $2.814 \mathrm{c}$ & 4193 & 0.613 & 0.695 \\
\hline T5 & $2.483 \mathrm{~d}$ & $2.745 \mathrm{c}$ & 4445 & 0.559 & 0.607 \\
\hline T6 & $2.526 \mathrm{~cd}$ & $2.907 \mathrm{c}$ & 4567 & 0.553 & 0.646 \\
\hline T7 & $2.197 \mathrm{e}$ & $2.452 \mathrm{~d}$ & 4463 & 0.492 & 0.498 \\
\hline T8 & $2.037 \mathrm{e}$ & $2.272 \mathrm{~d}$ & 4813 & 0.423 & 0.445 \\
\hline
\end{tabular}

Table 4. Effect of transplanting methods on grain and straw yield of Rice (Oryza sativa $\mathbf{L}$.) under normal soil conditions

\begin{tabular}{|c|c|c|c|c|}
\hline Treatments & $\begin{array}{c}\text { Grain yield } \\
\text { (ton/fed) }\end{array}$ & $\begin{array}{c}\text { Relative Change } \pm \% \\
\text { compared to } \mathrm{T} 1\end{array}$ & Straw yield (ton/fed) & $\begin{array}{l}\text { Relative change } \% \\
( \pm) \text { compared to } \mathrm{T} 1\end{array}$ \\
\hline \multicolumn{5}{|c|}{ Irrigation system (I) } \\
\hline T1 & $3.337 \mathrm{a}$ & 00.0 & $3.652 b$ & 00.0 \\
\hline $\mathrm{T} 2$ & $3.445 \mathrm{a}$ & 3.13 & $3.963 \mathrm{a}$ & 8.52 \\
\hline $\mathrm{T} 3$ & $2.875 \mathrm{~b}$ & -13.84 & $3.411 \mathrm{c}$ & -6.60 \\
\hline $\mathrm{T} 4$ & $2.583 \mathrm{c}$ & -22.60 & $2.913 \mathrm{~d}$ & -20.24 \\
\hline $\mathrm{T5}$ & $2.347 \mathrm{~d}$ & -29.67 & $2.699 \mathrm{e}$ & -26.10 \\
\hline T6 & $2.572 \mathrm{c}$ & -22.92 & $2.948 \mathrm{~d}$ & -19.28 \\
\hline $\mathrm{T} 7$ & $1.969 \mathrm{e}$ & -40.99 & $2.221 \mathrm{f}$ & -39.18 \\
\hline $\mathrm{T} 8$ & $1.843 \mathrm{f}$ & -44.77 & $2.141 \mathrm{~g}$ & -41.37 \\
\hline F-test & $* *$ & - & $* *$ & - \\
\hline
\end{tabular}

\footnotetext{
** Highly significant at 0.01 probability level.
} 
Table 5. Effect of transplanting methods on yield and yield components of rice (Oryza sativa L.) under normal soil conditions

\begin{tabular}{ccccccc}
\hline Treatments & $\begin{array}{c}\text { 1000 grain } \\
\text { weight }(\mathbf{g})\end{array}$ & $\begin{array}{c}\text { Panicle } \\
\text { weight }(\mathbf{g})\end{array}$ & $\begin{array}{c}\text { No. of grains/ } \\
\text { panicle }\end{array}$ & $\begin{array}{c}\text { No. of tillers/ } \\
\text { hill }\end{array}$ & $\begin{array}{c}\text { Panicle } \\
\text { length }(\mathbf{c m})\end{array}$ & $\begin{array}{c}\text { Plant height } \\
\text { (cm) }\end{array}$ \\
\hline $\mathrm{T} 1$ & $20.56 \mathrm{~b}$ & $3.03 \mathrm{de}$ & $132.5 \mathrm{a}$ & $14.75 \mathrm{c}$ & $21.25 \mathrm{be}$ & $79.0 \mathrm{c}$ \\
\hline $\mathrm{T} 2$ & $21.96 \mathrm{a}$ & $3.76 \mathrm{a}$ & $119.7 \mathrm{~b}$ & $20.25 \mathrm{a}$ & $21.75 \mathrm{ab}$ & $90.0 \mathrm{a}$ \\
\hline $\mathrm{T} 3$ & $22.28 \mathrm{a}$ & $3.3 \mathrm{~cd}$ & $95.5 \mathrm{~d}$ & $18.5 \mathrm{~b}$ & $17.75 \mathrm{~d}$ & $81.5 \mathrm{bc}$ \\
\hline $\mathrm{T} 4$ & $22.00 \mathrm{a}$ & $3.49 \mathrm{be}$ & $133.5 \mathrm{a}$ & $15.0 \mathrm{c}$ & $21.25 \mathrm{be}$ & $83.5 \mathrm{~b}$ \\
\hline $\mathrm{T} 5$ & $22.76 \mathrm{a}$ & $3.27 \mathrm{~cd}$ & $132.5 \mathrm{a}$ & $16.0 \mathrm{c}$ & $22.75 \mathrm{a}$ & $88.5 \mathrm{a}$ \\
\hline $\mathrm{T} 6$ & $22.24 \mathrm{a}$ & $3.98 \mathrm{a}$ & $121.7 \mathrm{~b}$ & $18.25 \mathrm{~b}$ & $21.5 \mathrm{ab}$ & $80 \mathrm{be}$ \\
\hline $\mathrm{T} 7$ & $23.08 \mathrm{a}$ & $2.65 \mathrm{e}$ & $95.5 \mathrm{~d}$ & $10.0 \mathrm{~d}$ & $21.25 \mathrm{be}$ & $83.25 \mathrm{~b}$ \\
\hline $\mathrm{T} 8$ & $22.68 \mathrm{a}$ & $3.26 \mathrm{~cd}$ & $111.0 \mathrm{c}$ & $9.25 \mathrm{~d}$ & $20.0 \mathrm{c}$ & $83.25 \mathrm{~b}$ \\
\hline F-test & $* *$ & $* *$ & $* *$ & $* *$ & $* *$ & $* *$ \\
\hline
\end{tabular}

** Highly significant at 0.01 probability level.

Table (6) revealed that the panicle length $(\mathrm{cm})$ of the rice has been highly significantly increased by transplanting methods and the highest value was obtained with transplanting method (T5). And plant height $(\mathrm{cm})$ has been highly significantly increased by transplanting methods. The highest mean value $(96.2$ $\mathrm{cm}$ ) was obtained by treatment (T2).

Effect of transplanting methods on yield and yield components of rice under saline soil condition:

Table (6) the results indicated that the maximum rice grain yield ( 3.23 ton/fed) was produced by the treatment of T2 while, the other treatments (T1, T3, T4, T5, T6 and T7) produced comparatively lower paddy grain yield each of $(2.805,2.821,2.570,2.483,2.5262 .197$, and 2.037 ton /fed). Results indicated that the maximum values of relative change $\pm \%$ was increased by $15.15 \%$ with the treatment of $\mathrm{T} 2$ as compared with traditional irrigation method (T1) on the other hand, grain yield was decreased by $27.38 \%$ with the treatment $\mathrm{T} 8$ compared with traditional irrigation method (T1).

Data in table (6) showed that, the maximum rice straw yield $\left(4.212,4.132\right.$ ton fed $\left.^{-1}\right)$ was produced by the treatment of $\mathrm{T} 1$ and $\mathrm{T} 2$ with no significant difference between them while, the other treatments (T3, T4, T5, T6, T7and T8) produced comparatively lower paddy straw yield each of $(3.213,2.814,2.745,2.9072 .452$ and 2.272 ton $\mathrm{fed}^{-1}$ ), respectively, under saline soil condition.

Data in Table (7) indicated that the 1000 grain weights, panicle weight $(\mathrm{g})$, no. of grains/panicle, no. of tillers/plant, panicle length $(\mathrm{cm})$ and plant height $(\mathrm{cm})$ of the rice, have been highly significantly affected by transplanting methods.

The highest mean values of 1000 grain weight and no. of tillers/plant was recorded by transplanting methods (T7) as compared with traditional transplanting methods, (T4) and (T3) recorded the highest numerical values for panicle weight and panicle length , respectively. The transplanting method (T4) recorded the highest mean value for no. of grains/panicle and plant height.

\section{Economic evaluation:}

Table (8) the results show that the values of variable, fixed and total costs (LE/fed.) as affected by treatments applied in normal and saline soils indicated that the total costs were 3510,3430 and $3410 \mathrm{LE} /$ fed for the T1, T2 and T3, respectively. While, the total costs for the other treatments are similar (3360 LE/fed.). Also, the same tables illustrated the values of grain yield, total income (LE/fed.) and net profit. The highest values of total income (6890 and $6460 \mathrm{LE} / \mathrm{fed}$.) were obtained from T2 treatment, while the lowest values (3686 and 4074 LE/fed.) were recorded with T8 treatment. This increase of total income could be attributed to highest grain yield achieved by $\mathrm{T} 2$.

\section{Water productivity and economic efficiency:}

Table (9) illustrated that the maximum values of water productivity $(0.59$ and $0.53 \mathrm{LE} / \mathrm{m} 3)$ were obtained from the treatment of $\mathrm{T} 2$ and under normal and saline soil conditions, respectively. However, the differences between T2 and T3 were very small. While, the lowest one $(0.07$ and $0.15 \mathrm{LE} / \mathrm{m} 3)$ for T8 under normal and saline soil conditions, respectively.

It was observed that the regular transplanting achieved higher grain yield and water productivity than the transplanting rice on beds and furrows.

Concerning the economic efficiency, the increasing net return or profit for crops refers to the decreasing of production costs or increasing the crop production. So, economic efficiency index refers to the agricultural and irrigation activities which can give the highest return from each Egyptian pound unit which can spend on crop production. 
Table 6. Effect of transplanting methods on grain and straw yield of rice (Oryza sativa L.) under saline soil condition

\begin{tabular}{ccccc}
\hline Treatments & Grain yield (ton/ fed) & Relative Change \pm \% & Straw yield (ton /fed) & Relative change \% $( \pm)$ \\
\hline \multicolumn{5}{c}{ Transplanting methods } \\
\hline $\mathrm{T} 1$ & $2.805 \mathrm{bc}$ & 00.0 & $4.212 \mathrm{a}$ & 00.0 \\
\hline $\mathrm{T} 2$ & $3.23 \mathrm{a}$ & 15.15 & $4.132 \mathrm{a}$ & -1.90 \\
\hline $\mathrm{T} 3$ & $2.821 \mathrm{~b}$ & 0.57 & $3.213 \mathrm{~b}$ & -23.72 \\
\hline $\mathrm{T} 4$ & $2.570 \mathrm{bcd}$ & -8.38 & $2.814 \mathrm{c}$ & -33.19 \\
\hline $\mathrm{T} 5$ & $2.483 \mathrm{~d}$ & -11.48 & $2.745 \mathrm{c}$ & -34.83 \\
\hline $\mathrm{T} 6$ & $2.526 \mathrm{~cd}$ & -9.95 & $2.907 \mathrm{c}$ & -30.98 \\
\hline $\mathrm{T} 7$ & $2.197 \mathrm{e}$ & -21.68 & $2.452 \mathrm{~d}$ & -41.79 \\
\hline $\mathrm{T} 8$ & $2.037 \mathrm{e}$ & -27.38 & $2.272 \mathrm{~d}$ & -46.06 \\
\hline F-test & $* *$ & - & $* *$ & - \\
\hline$* *$ Highly significant at 0.01 probability level. & & &
\end{tabular}

Table7. Effect of transplanting methods on yield and yield components of rice (Oryza sativa L.) under saline soil condition

\begin{tabular}{ccccccc}
\hline Treatments & $\begin{array}{c}\text { 1000 grain } \\
\text { weight (g) }\end{array}$ & $\begin{array}{c}\text { Panicle } \\
\text { weight (g) }\end{array}$ & $\begin{array}{c}\text { No. of grains/ } \\
\text { panicle }\end{array}$ & $\begin{array}{c}\text { No. of tillers/ } \\
\text { hill }\end{array}$ & $\begin{array}{c}\text { Panicle length } \\
\text { (cm) }\end{array}$ & $\begin{array}{c}\text { Plant height } \\
(\mathbf{c m})\end{array}$ \\
\hline $\mathrm{T} 1$ & $19.8 \mathrm{ab}$ & $2.47 \mathrm{~b}$ & $116.0 \mathrm{c}$ & $14.8 \mathrm{abc}$ & $2.47 \mathrm{~b}$ & $88 \mathrm{be}$ \\
\hline $\mathrm{T} 2$ & $19.88 \mathrm{ab}$ & $2.80 \mathrm{ab}$ & $113.0 \mathrm{c}$ & $15.3 \mathrm{ab}$ & $2.80 \mathrm{ab}$ & $94.25 \mathrm{a}$ \\
\hline $\mathrm{T} 3$ & $19.28 \mathrm{abc}$ & $2.93 \mathrm{a}$ & $123.5 \mathrm{~b}$ & $14.5 \mathrm{be}$ & $2.93 \mathrm{a}$ & $87.25 \mathrm{c}$ \\
\hline $\mathrm{T} 4$ & $17.56 \mathrm{c}$ & $3.04 \mathrm{a}$ & $129.3 \mathrm{a}$ & $14 \mathrm{~cd}$ & $3.04 \mathrm{a}$ & $96.2 \mathrm{a}$ \\
\hline $\mathrm{T} 5$ & $18.12 \mathrm{be}$ & $2.76 \mathrm{ab}$ & $121.0 \mathrm{~b}$ & $15.3 \mathrm{ab}$ & $2.76 \mathrm{ab}$ & $92.5 \mathrm{ab}$ \\
\hline $\mathrm{T} 6$ & $20.44 \mathrm{a}$ & $2.71 \mathrm{ab}$ & $121.0 \mathrm{~b}$ & $14 \mathrm{~cd}$ & $2.71 \mathrm{ab}$ & $94.75 \mathrm{a}$ \\
\hline $\mathrm{T} 7$ & $20.56 \mathrm{a}$ & $2.99 \mathrm{a}$ & $100.0 \mathrm{~d}$ & $15.8 \mathrm{a}$ & $2.99 \mathrm{a}$ & $83.5 \mathrm{~cd}$ \\
\hline $\mathrm{T} 8$ & $19.32 \mathrm{abc}$ & $2.02 \mathrm{c}$ & $96.0 \mathrm{~d}$ & $13 \mathrm{~d}$ & $2.02 \mathrm{c}$ & $80.5 \mathrm{~d}$ \\
\hline F. test. & $* *$ & $* *$ & $* *$ & $* *$ & $* *$ & $* *$ \\
\hline
\end{tabular}

** Highly significant at 0.01 probability level.

Table 8.Values of grain yield (kg/fed.) total income (LE/fed.), total cost (LE/fed.) and net profit (LE/fed.) as affected by different transplanting methods under normal and saline soils conditions

\begin{tabular}{|c|c|c|c|c|c|c|}
\hline \multirow[t]{2}{*}{ Treatments } & \multirow{2}{*}{$\begin{array}{c}\text { Grain yield } \\
(\mathrm{kg} / \mathrm{fed})\end{array}$} & \multirow{2}{*}{$\begin{array}{l}\text { Total income } \\
\text { (LE/fed.) }\end{array}$} & \multicolumn{3}{|c|}{ Production cost (LE/fed.) } & \multirow{2}{*}{$\begin{array}{c}\text { Net Profit } \\
\text { (LE/fed.) }\end{array}$} \\
\hline & & & Variable & Fixed & Total & \\
\hline \multicolumn{7}{|c|}{ Normal soil } \\
\hline $\mathrm{T} 1$ & 3337 & 6674 & 1560 & 1950 & 3510 & 3164 \\
\hline $\mathrm{T} 2$ & 3445 & 6890 & 1480 & 1950 & 3430 & 3460 \\
\hline T3 & 2875 & 5750 & 1460 & 1590 & 3410 & 2340 \\
\hline $\mathrm{T} 4$ & 2583 & 5166 & 1410 & 1950 & 3360 & 1806 \\
\hline T5 & 2347 & 4694 & 1410 & 1950 & 3360 & 1334 \\
\hline T6 & 2572 & 5144 & 1410 & 1950 & 3360 & 1754 \\
\hline $\mathrm{T} 7$ & 1969 & 3938 & 1410 & 1950 & 3360 & 578 \\
\hline $\mathrm{T} 8$ & 1843 & 3686 & 1410 & 1950 & 3360 & 326 \\
\hline \multicolumn{7}{|c|}{ Saline soil } \\
\hline T1 & 2805 & 5610 & 1560 & 1950 & 3510 & 2100 \\
\hline $\mathrm{T} 2$ & 3230 & 6460 & 1480 & 1950 & 3430 & 3030 \\
\hline T3 & 2821 & 5642 & 1460 & 1950 & 3410 & 2232 \\
\hline $\mathrm{T} 4$ & 2570 & 5140 & 1410 & 1950 & 3360 & 1780 \\
\hline T5 & 2483 & 4966 & 1410 & 1950 & 3360 & 1606 \\
\hline T6 & 2526 & 5052 & 1410 & 1950 & 3360 & 1692 \\
\hline $\mathrm{T} 7$ & 2147 & 4394 & 1410 & 1950 & 3360 & 1034 \\
\hline T8 & 2037 & 4074 & 1410 & 1950 & 3360 & 714 \\
\hline
\end{tabular}


Table 9.Water productivity $\left(\mathrm{LE} / \mathrm{m}^{3}\right)$ and economic efficiency for rice crop as affected by different transplanting method under normal and saline soils conditions

\begin{tabular}{|c|c|c|c|c|c|}
\hline Treatments & $\begin{array}{l}\text { Net profit, } \\
\text { LE/fed. }\end{array}$ & $\begin{array}{c}\text { Total water } \\
\text { applied, } \mathbf{m}^{3} / \mathbf{f e c}\end{array}$ & $\begin{array}{c}\text { Water productivity, } \\
\mathrm{LE} / \mathrm{m}^{3}\end{array}$ & $\begin{array}{l}\text { Total production } \\
\text { cost, LE/fed. }\end{array}$ & $\begin{array}{l}\text { Economic } \\
\text { efficiency }\end{array}$ \\
\hline \multicolumn{6}{|c|}{ Normal soil } \\
\hline T1 & 3164 & 6485 & 0.49 & 3510 & 0.9 \\
\hline $\mathrm{T} 2$ & 3460 & 5831 & 0.59 & 3430 & 1.01 \\
\hline $\mathrm{T} 3$ & 2340 & 4125 & 0.57 & 3410 & 0.69 \\
\hline $\mathrm{T} 4$ & 1806 & 3982 & 0.45 & 3360 & 0.54 \\
\hline T5 & 1334 & 4315 & 0.31 & 3360 & 0.4 \\
\hline T6 & 1784 & 4475 & 0.40 & 3360 & 0.53 \\
\hline $\mathrm{T} 7$ & 578 & 4395 & 0.13 & 3360 & 0.17 \\
\hline T8 & 326 & 4658 & 0.07 & 3360 & 0.10 \\
\hline \multicolumn{6}{|c|}{ Saline soil } \\
\hline $\mathrm{T} 1$ & 2100 & 6675 & 0.31 & 3510 & 0.60 \\
\hline $\mathrm{T} 2$ & 3030 & 5978 & 0.51 & 3430 & 0.88 \\
\hline T3 & 2232 & 4245 & 0.53 & 3410 & 0.65 \\
\hline $\mathrm{T} 4$ & 1780 & 4193 & 0.42 & 3360 & 0.53 \\
\hline T5 & 1606 & 4445 & 0.36 & 3360 & 0.48 \\
\hline T6 & 1692 & 4567 & 0.37 & 3360 & 0.50 \\
\hline $\mathrm{T} 7$ & 1034 & 4463 & 0.23 & 3360 & 0.31 \\
\hline $\mathrm{T} 8$ & 714 & 4813 & 0.15 & 3360 & 0.21 \\
\hline & \multirow{2}{*}{\multicolumn{2}{|c|}{ Water productivity }} & \multicolumn{2}{|l|}{ Net profit } & \\
\hline & & & \multirow{2}{*}{\multicolumn{2}{|c|}{$\begin{array}{l}\text { Amount of water applied } \\
\text { Net profit }\end{array}$}} & \\
\hline & \multicolumn{2}{|c|}{ Economic efficiency } & & & \\
\hline
\end{tabular}

Also the values of economic efficiency were 0.9 , $1.01,0.69,0.54,0.40,0.53,0.17$ and 0.1 and $0.6,0.88$, $0.65,0.53,0.48,0.5,0.31$ and 0.21 for $\mathrm{T} 1, \mathrm{~T} 2, \mathrm{~T} 3, \mathrm{~T} 4$, T5, T6, T7 and T8 treatments under normal and saline soil conditions, respectively.

It was noticed that, the economic efficiency increased in case of regular transplanting treatment (1.01 and 0.88) due to maximum yield in normal and saline soils, respectively. While, the lowest values of economic efficiency $(0.1$ and 0.21$)$ were obtained in case of transplanting on beds and bottom of furrows with $60 \mathrm{~cm}$ wide (T8). These increases in economic efficiency are due to the enhancement of net profit in (T2) treatments compared with the other treatments.

\section{REFERENCES}

Atta, Y.I.M. (2005). Strip transplanting of rice: a new method for increasing water use efficiency under splitting of nitrogen fertilizer. Egypt. J. of Appl. Sci., 20(10b): 501511.

Atta, Y.I.M.; M.E. Meleha; U.M. Gawish and A.T. Abd ElAal (2006). Improving water productivity in rice cultivation with high potential for water saving. The Arab Water Regional Conference, 2006, December 9/11/2006 (NWRC) Egypt.

Black, C.A. (1965). Methods of Soil Analysis. Amer. Soc. Agron. Inc. Madison, Wisconsin, USA.
Dewis, J. and F. Ferias (1970). Physical and chemical methods of soil and water analysis. Soils Bulletin No. 10 FAO, Rome.

Israelson, O. W. and V. E. Hansen, 1962, "Irrigation Principals and Practices", 3rd ed. John Welly and Sons Inc. New York.

Jackson, M.L. (1967). Soil chemical analysis. Principle Hall of India, New Delhi.

Jagroop, P.K.; R.K. Mahey; K.K. Vashist and S.S. Manal (2007). Growth and productivity of rice (Oryza sativa L.) and water expense efficiency as influenced by different planting techniques. Environment and Ecology, 25(1): 235-238.

James, L.G. (1988). Principles of farm irrigation system design. John Willey \& Sons Ltd., New York, pp. 543.

Meleha, M.E.; A.Z. El-Bably; A.A. Abd Allah and W.M. ElKhoby (2008). Producing more rice with less water by inducing planting methods in North Delta, Egypt. J. Agric. Sci. Mansoura Univ., 33(1): 805-813.

Michael, A.M. (1978). Irrigation theory and practices. Vikas Publishing House Put Ltd. New Delhi, Bombay.

Michael, A.M. (1978). Irrigation theory and practices. Vikas Publishing House Put Ltd. New Delhi, Bombay.

Ockerby, S.E. and S. Fukaib (2001). The management of rice grown on raised beds with continuous furrow irrigation. Field Crops Research, 69(3): 215-226.

Snedecor, G.W. and W.G. Cochran (1980). "Statistical Methods" 7th ed., 225-330. Iowa state Univ., Press., Ames., Iowa, USA. 


\section{الملخص العربي}

تعظيم إنتاجية المياه والحصول من خلال طرق شتل الأرز تحت ظروف الاراضى الملحية وغير الملحية في شنمال الدلتا- مصر

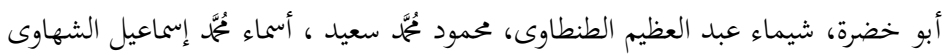

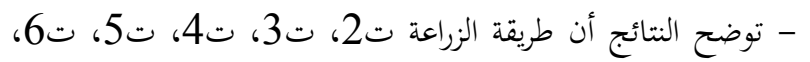

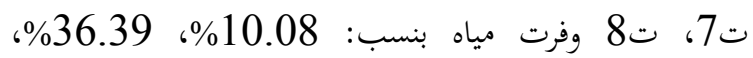

، \%33.14 ، \%33.46

27.89\% على التوالى مقارنة بطريقة الزراعة التقليدية.

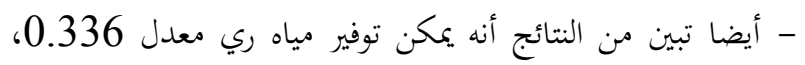

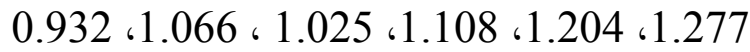
ק3/فدان مع المعاملات ت2، ت4، ت5، ت6، ت7 ت7 ت مقارنة بطريقة الشتل التقليدي. - تبين من النتائج أن أعلى قيم كفاءة استخدام المياه تمت مع المعاملة

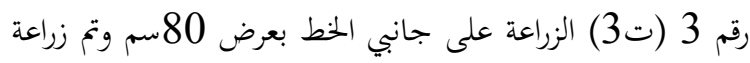

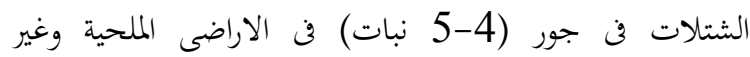
الملحية. بينما سجلت كفاءة استعمال المياه أقل القيم عند استخدام طريقة الشتل التقليدى (ت1 في الاراضى الملحية وغير الملحية.

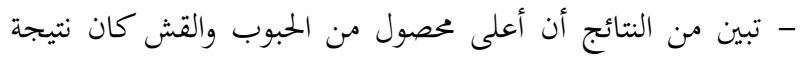

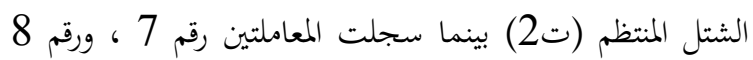
أقل محصول من الحبوب فن الاراضى الملحية وغير الملحية.

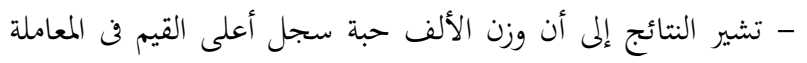

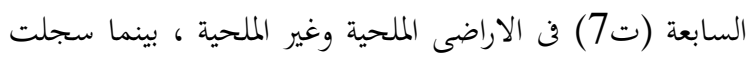

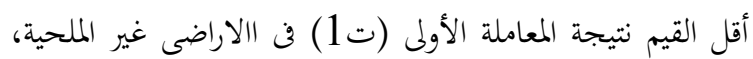
والمعاملة الرابعة (ت4) في الاراضى الملحية.

التقييم الاقتصادي:

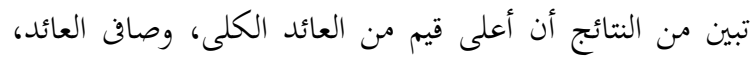
وإنتاجية المياه، والكفاءة الاقتصادية تم التحصل عليها نتيجة استخدام

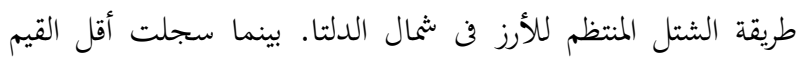

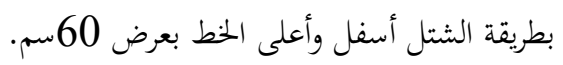

تم إجراء بتربتين حقليتين بنجاح خلال موسم الزراعة 2009

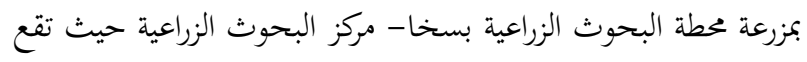

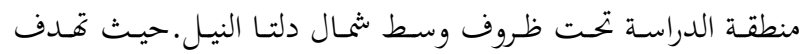

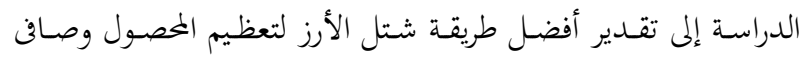

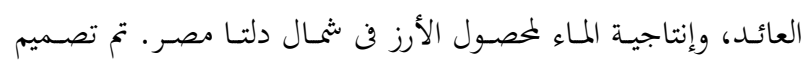

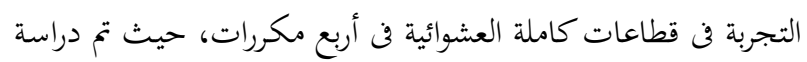
ثمانية معاملات فن الحقل المستديع وهى كالتالي:

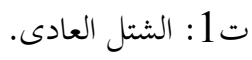
ت2: الشتل المنتظم. (على مسافة 20x20 الثتل العادم). ت3: الشتل فن جور على مصاطب عرضها 80سم على الجانبين من أسفل(4-5 نبات/جورة).

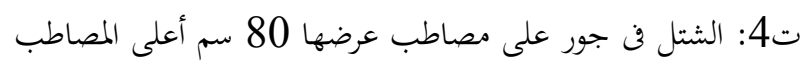
(5-4 نبات/جورة).

ت5: الشتل فن جور على مصاطب عرضها 80سم أعلى وأسفل المصاطب (4-5 نبات/جورة).

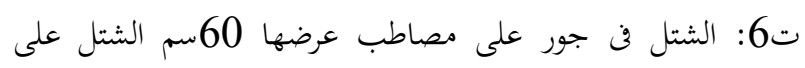
الجانبين (4-5 نبات/جورة).

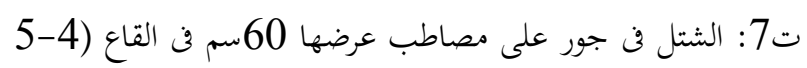

$$
\text { نبات/جورة). }
$$

8: الشتل فن جور على مصاطب عرضها 60سم الزراعة أعلى

$$
\text { وأسفل المصطبة (4-5 نبات فئجورة). }
$$

يككن تلخيص أهم النتائج المتحصل عليها من فيما يلي:

- تبين من النتائج أن طريقة الزراعة بالشتل العادي (التقليدي)

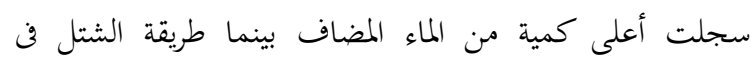

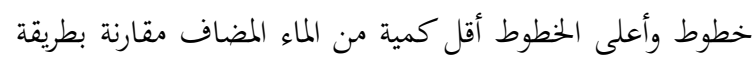

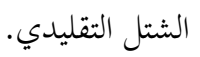

